\author{
Luciana Hartmann
}

Universidade Federal de Santa Maria

\title{
Do campo à "Campanha": gênero, performance e narrativas orais na fronteira entre o Brasil e o Uruguai
}

\begin{abstract}
Resumo: Neste artigo abordo questões referentes à configuração dos papéis de gênero entre contadoras e contadores de "causos" da região da fronteira entre Brasil e Uruguai, considerando também o papel da pesquisadora nesse contexto. Na pesquisa etnográfica realizada, as diferenças entre os gêneros foram gradualmente revelando sua importância para o estudo das histórias narradas e, consequentemente, para a compreensão da sociedade fronteiriça. Assim como na organização social local percebe-se uma clara divisão do trabalho, do tempo e dos espaços ocupados por homens e mulheres, também nas narrativas orais e nas suas performances essa divisão encontrará correspondência. Levando em conta esses aspectos, procuro demonstrar de que maneira, seja no conteúdo das narrativas, seja na forma de contá-las, essas diferenças vão sendo demarcadas.
\end{abstract}

Palavras-chave: oralidade; performances narrativas; fronteira; papéis de gênero.

Copyright (c) 2010 by Revista Estudos Feministas.

1 Utilizo o conceito de "papel", ligado ao gênero, como "representação de um personagem", relativo àquilo que culturalmente está associado ao sexo biológico e determina os papéis de fêmea ou macho numa dada sociedade (Miriam Pillar GROSSI, 1998). Restrinjo-me aos papéis de gênero porque creio que essa seja a abordagem que melhor se adéque ao novo olhar que pretendo dar, neste trabalho, aos meus dados etnográficos.
A compreensão da importância e do significado dos papéis de gênero' para os habitantes da zona fronteiriça entre Argentina, Brasil e Uruguai não estava, inicialmente, entre os objetivos de minha pesquisa. A etnografia realizada com contadoras e contadores de "causos" da região, entretanto, logo demonstrou que um olhar mais acurado sobre essa divisão de papéis seria fundamental para a compreensão não somente das histórias narradas como também da própria sociedade estudada. Neste artigo procuro explorar as configurações dos gêneros nessa zona de fronteira, contemplando os encontros etnográficos entre os sujeitos pesquisados e a pesquisadora que esteve entre eles, eu. Tenho claro que meu olhar dificilmente dará conta de enxergar toda a complexidade do tema, espalhado na vastidão daquelas planícies pampeanas. Meu propósito aqui, 
${ }^{2} \mathrm{~A}$ abordagem das narrativas orais através da noção de performance é orientada pela obra de Esther Jean LANGDON, 1996, 1999 e 2007, a quem agradeço as inúmeras contribuições feitas ao meu trabalho.

${ }^{3}$ Ondina Fachel LEAL, 1989.

\footnotetext{
4 Joan SCOTT, 1990.

${ }^{5}$ Chantal MOUFFE, 2000.

${ }^{6}$ Embora compreenda as proposições em favor da existência de uma igualdade biológica entre as mulheres e de uma desigualdade estrutural entre homens e mulheres ou de uma igualdade substancial de todas as mulheres, neste trabalho optei por considerar, como menciono acima, as relações de igualdade e diferença também "intra"-gêneros, ou seja, entre mulheres e mulheres e entre homens e homens. Problematizando os enfoques sobre a questão das igualdades e diferenças de gênero, Signe HOWELL e Marit MELHUSS, 1993 expandem o debate questionando ainda como estabelecer e calcular "as diferenças que fazem a diferença".
}

portanto, não excederá o levantamento de algumas hipóteses, experimentando com o jogo dialógico da escrita possíveis análises sobre as representações dos gêneros na região. E como minha pesquisa foi voltada para as performances dos "causos", sirvo-me delas e de minha experiência subjetiva no campo para realizar essas análises. ${ }^{2}$

Não poderia deixar de fazer referência, já de início, a um trabalho que de certa forma inaugura a abordagem de gênero sobre a região, a tese de Ondina Fachel Leal, ${ }^{3}$ voltada para a relação entre cultura masculina e identidade nos Pampas. Para a autora, que pesquisou na região nos anos 1980, gênero e cultura na região da fronteira dos Pampas são inseparáveis. Segundo ela, os gaúchos entendidos como trabalhadores rurais, peões de estância , que vivem e trabalham segregados das mulheres, formam um grupo exclusivamente masculino, calcado em valores como honra, liberdade e coragem, e acabam identificando a região à masculinidade. Em minha pesquisa, iniciada no final da década de 1990, optei por não partir do pressuposto de que a cultura gaúcha fosse igual à cultura masculina pois acreditava que isso me fizesse ficar mais atenta às sutilezas do campo. Este artigo é um reflexo de minha trajetória nesse sentido. Não é minha intenção, entretanto, realizar uma abordagem pontuada em relação à de Leal, pois, enquanto ela sustenta uma tese sobre o assunto, restrinjo-me aqui a uma aventura analítica sobre a relação entre gênero, performances e narrativas. A perspectiva que adotarei ao longo do texto, porém, é semelhante à de Leal, que vê o gênero como relacional. A noção de que o gênero é constituído nas relações sociais - sempre marcadas por relações de poder - tem como fonte principal a discussão instaurada por Joan Scott ${ }^{4}$ no final dos anos 1980, e tanto a abordagem de Leal quanto a minha, nesse sentido, alinhamse à da autora.

Embora considere que a questão da identidade de gênero só seja possível a partir da constatação da diferença, da relação com a alteridade, ${ }^{5}$ não pretendo, contudo, assumir essas diferenças como absolutas, mas como dinâmicas e inseridas num contexto onde inúmeros critérios sociais estão em constante negociação (além do gênero, da classe social, da faixa etária, da raça, do capital simbólico etc.). Dessa forma, mesmo as relações de igualdade e diferença entre homens e mulheres podem e serão aqui analisadas nas suas nuances constitutivas, ou seja, também entre homens e homens e entre mulheres e mulheres. $^{\circ}$ 


\section{O gênero na história e na memória dos habitantes da fronteira}

${ }^{7} \mathrm{~A}$ Campanha é uma das microrregiões geográficas do Rio Grande do Sul onde estão localizadas algumas das cidades brasileiras que foram objeto desta pesquisa (Uruguaiana, Alegrete, Quaraí e Sant'Anna do Livramento). Já o termo "campanha" é utilizado por toda a população no sentido de campo ou zona rural.

${ }^{8}$ Sandra PESAVENTO, 1994.

${ }^{9}$ Michael HERZFELD, 1985.

${ }^{10}$ Robert William CONNELL, 1995.

1 Miguel VALE DE ALMEIDA, 1995.
A Campanha ${ }^{7}$ localiza-se numa zona limítrofe, na fronteira entre três países, Brasil, Argentina e Uruguai, e até que essas fronteiras fossem estabelecidas e afirmadas, muito sangue teve de ser derramado no Rio Uruguai, nos inúmeros conflitos armados que definiram os atuais contornos geopolíticos da região. Último território ocupado pelos portugueses, quase dois séculos depois do restante do que viria a ser o Brasil, o Rio Grande do Sul tem sua história marcada por inúmeras guerras, revoluções e combates armados amplamente noticiados na historiografia nacional e local. Mas o "pegar em armas" nem sempre esteve relacionado à posse de terras: muitas vezes foi a luta pela autonomia econômica (Revolução Farroupilha, 1835-1845) ou pelo poder político (Revolução Federalista, 1983-1985) que levou ao combate, ${ }^{8}$ ou ainda, uma vingança, uma desfeita, um mal-entendido, uma traição... A partir de um dado momento da história temse a impressão de que não era o motivo, mas a luta em si, que mobilizava toda uma parte daquela população. Pelo prazer do desafio a sociedade se organizava.

Mas quem usufrui desse prazer? Encontrei algumas respostas nos inúmeros comentários e reclamações das mulheres sobre o excessivo risco a que alguns homens (esposos, filhos, irmãos) se expõem, por exemplo, no trabalho. Isso ocorre, segundo elas, desnecessariamente, por prazer. Esse é o caso do roubo de animais, que caracteriza a "surpresa". A "surpresa" era uma atividade comum em toda a fronteira até bem poucos anos, mas se tornou rara atualmente. Era uma espécie de festividade, em geral comemorativa de um aniversário, na qual os vizinhos roubavam um novilho dos campos do aniversariante, carneavam, assavam e no dia seguinte iam, em caravana, dar a "surpresa". Essas eram ocasiões nas quais se reunia toda a vizinhança e a presença de músicos (gaiteiros, violeiros...) era fundamental para garantir o baile, que podia durar até três dias. $O$ "detalhe" é que nem sempre o aniversariante ficava feliz de ser roubado... É interessante perceber - como o fez Michael Herzfeld ${ }^{9}$ em sua pesquisa numa comunidade cretense - que essa atividade é protagonizada sempre pelos homens. Através dessa forma de desafio eles vão estabelecendo laços sociais e construindo sua identidade masculina, ou seja, o desenvolvimento da masculinidade se dá de acordo com o posicionamento do indivíduo na rede de relações sociais. Essa "instabilidade" da identidade masculina vem sendo tratada teoricamente por autores como Robert Connell ${ }^{10}$ e Miguel Vale de Almeida" ${ }^{1}$, entre outros, e, corroborando com essa ideia, Leal afirma que a identidade do homem gaúcho é 
12 Há, no entanto, algumas sugestões ou alusões sutis ao fato, especialmente nas narrativas contadas por mulheres, abordadas a seguir. Em termos de registros escritos, as referências são escassas. Notese, porém, que a violência citada é referente não a uma ação de gaúchos, mas do ditador paraguaio (o que, segundo Élio Chaves FLORES, 1996, p. 119, é comum, na historiografia gaúcha, a transferência da violência para os inimigos): "Não podendo, porém, o ditador exercer vingança direta, exerceu sobre a família do infeliz coronel (Estigarribia), mandando entregar suas três filhas e a senhora à marinhagem de um navio ancorado no pôrto. É inacreditável [...]". Buscando fontes da época, Ivo CAGGIANI, 1990, p. 35-36, também levanta dados, no jornal de Rivera/UY de agosto de 1893, que registram esse tipo de violência. Há ainda o trabalho de EIma SANT'ANNA, 1984, menos crítico do que se esperaria, sobre "O folclore da mulher gaúcha".

${ }^{13}$ FLORES, 1996, p. 119.

14 Catherine LUTZ, 1995; Clarice MOTA, 1980, entre outras.

15 LEAL, 1989, p. 120. algo que está sempre em risco e que precisa ser constantemente reconquistada.

Apesar de estendido a um suposto "sujeito universal" gaúcho, parece-me que o prazer pelo risco revela (ou, ao contrário, oculta) um desejo referente apenas à parcela masculina da população. O fato de que o "povo gaúcho" vem sempre associado ao masculino fica explicitado quando se faz uma análise mais acurada da história oficial e também pode ser percebido em muitas narrativas orais contadas por homens: as mulheres estão invisíveis. Deviam estar em algum lugar, cuidando dos filhos, das terras, do gado, lutando para proteger a si e as suas propriedades, sofrendo violências, mas simplesmente não aparecem na grande maioria dos relatos. ${ }^{12}$ É como se não existissem, ou não fossem importantes:

Esquecida numa guerra de homens, desprezada pela história das batalhas militares, a mulher surge de circunstâncias inusitadas: ora como amante de homens vingativos, ora sofrendo a violência sexual destes e, tantas vezes, despedaçada com os filhos nos braços. ${ }^{13}$

É interessante constatar, entretanto, como o autor citado, apesar de trazer à tona essa importante questão, ainda trabalha com "a mulher", no singular, sem considerar, parece-me, as importantes nuances identitárias que integram cada papel de gênero.

Esse obscurecimento e desconsideração da participação das mulheres na história e em vários âmbitos da vida social, como nos contam várias autoras, ${ }^{14}$ é tão forte, constituindo de tal maneira nossa visão de mundo, que eu mesma cheguei ao campo pronta para ouvir os homens, afinal eles é que deveriam ser os contadores! Como já explicitei em outro trabalho, a inclusão das mulheres como contadoras de histórias em minha pesquisa não foi tão óbvia quanto deveria. Levei algum tempo até atribuir "legitimidade" àquelas narrativas contadas, por exemplo, pela cozinheira da Estância São Paulo, incansável em me explicar quem fazia o quê na complicada hierarquia de trabalho da estância ou em contextualizar as relações de parentesco dos moradores locais. Dona Rosa também contou intimidades e detalhes da história de sua família e, especialmente, foi ela quem me colocou a par das fofocas que circulavam pela boca, sobretudo, das mulheres da estância. De acordo com Leal, ${ }^{15}$ as fofocas, na região, não seriam apropriadas para o comportamento masculino, sendo caracterizadas pelos homens como "fala de mulher". Em minha pesquisa de campo, entretanto, constatei que, apesar do pretenso interdito social, os homens também sabem manipular habilmente as fofocas, dependendo do contexto de narração e do grau de intimidade e confiança no/na ouvinte. Embora somente depois 
${ }^{16}$ Jane HILL e Judith IRVINE, 1993, p. 16.

17 Jean-François LYOTARD, 1986.

${ }^{18}$ LYOTARD, 1986, p. 42.

${ }^{19}$ Adriana PISCITELLI, 1993, p. 160. de retornar da São Paulo eu tenha podido perceber a importância das narrativas de Dona Rosa, acabei concluindo que isso ocorreu porque ela própria não se reconhece como contadora, assim como não é reconhecida dessa maneira por parte dos outros habitantes da estância, já que não assume publicamente a "responsabilidade pelo conteúdo, pela forma ou pela origem das informações", questão importante, de acordo com Jane Hill e Judith Irvine, ${ }^{16}$ na atribuição do status de um contador.

Os contadores, portanto, precisam ser legitimados pela comunidade à qual pertencem. Para Jean-François Lyotard, ${ }^{17}$ uma coletividade estabelece seu vínculo social não apenas na significação dos relatos que ela conta, mas no ato de recitá-los, ou seja, na sua performance. Segundo ele, os critérios de competência desses relatos "definem assim o que se tem o direito de dizer e de fazer na cultura e, como também eles são uma parte desta, encontram-se desta forma legitimados". ${ }^{18}$ Talvez daqui possamos depreender o porquê de Dona Rosa e de muitas outras mulheres não possuírem legitimidade como contadoras: não somente a ênfase de seus relatos está no conteúdo (e, consequentemente, nos seus significados), como este, em muitos casos, não possui respaldo social, podendo ser transmitido apenas em situações de intimidade e segredo, ou seja, suas histórias não são para a coletividade. Devido a esse aspecto, grande parte das narrativas que pude registrar em áudio, vídeo e foto é masculina, pois as femininas não permitiam essa forma de registro.

Haveria, portanto, temáticas preponderantes nas lembranças femininas? Encontro uma pista para a resposta em artigo de Adriana Piscitelli ${ }^{19}$ sobre tradição oral, memória e gênero:

As linhas de investigação que se preocupam com particularidades do trabalho sexuado da memória sustentam, a partir de pesquisas específicas, que existe uma associação entre memória feminina e tradição genealógica. São lembranças das mulheres as que se relacionam com o domínio da família, da vida privada e doméstica.

Acompanhando essa perspectiva, a grande maioria das narrativas que ouvi das mulheres dizia respeito ao universo familiar, às relações de parentesco, da casa, da vida íntima. Em alguns casos foram elas, inclusive, que me revelaram um lado obscuro do comportamento de contadores famosos: de como um deles é violento com os filhos e a esposa, de outro que costuma envolver-se em roubos de gado, e assim por diante. Ao dizerem o "não-dito", elas estavam me abrindo uma nova perspectiva de visão daquele universo, ao mesmo tempo que também se inseriam nele 
${ }^{20} \mathrm{Na}$ transcrição das falas das contadoras optei por buscar, na escrita, uma aproximação com a linguagem oral, indicando também os principais aspectos que permitam compreender suas performances. através das suas histórias. Um dos exemplos nesse sentido foi dado por Dona Iracema, uruguaia de 77 anos, mãe de 22 filhos, que trabalhou como contrabandista na zona rural da fronteira:

[...] me foi mal o casamento. Não encontrei felicidade no casamento, viste? Ele me encheu de filho [...] Ele era [...] [faz um gesto indicativo de que ele bebia]. $A h$, isso é que me preocupava. Sim, pero eu vou te contar o causo dele: era horrible, horrible, horrible! Tu sabe que ele tentava me matar [...] e eu com as crianças. Nós disparava pro meio do campo! Eu cansei de dormir no campo. [ela muda de idioma] Porque la madre es como la gallina, si veinte hijos tiene, a los veinte hace có có có có y a todos los tapa con las alas, con las patitas. Y la madre es lo mismo. Una mala comparación no es, no? Es lo mismo, es lo mismo. Yo me iba para as cuchillas dormir, de miedo que ele matara [...] a mi no me importava que me matara, pero a mis hijos. Por eso llevaba todos conmigo $\left[\ldots . .{ }^{20}\right.$

Ao contrário de grande parte das histórias que escutei dos homens, voltadas para episódios épicos, grandiosos, proezas e façanhas de suas trajetórias, a narrativa de Dona Iracema estampa, de forma semelhante à de outras mulheres, um desejo de dar a conhecer ("eu vou te contar o causo dele") as violências e os dramas sofridos, episódios nem por isso vergonhosos de sua história pessoal. A revelação dos "não-ditos" por parte das mulheres, no entanto, não se insere num dualismo sexualizado absoluto, ou seja, as mulheres não tratam apenas dos segredos e da intimidade de homens, mas também de outras mulheres e de si mesmas. Vejamos como Simone, de 45 anos, empresária de Sant'Anna do Livramento/BR, aborda essa questão em uma de suas narrativas:

O alcoolismo foi uma coisa que existiu a vida inteira, em homens e mulheres, mas as famílias resguardavam bastante. Eu conheço pessoalmente um caso, de uma pessoa da geração da minha mãe, que era alcoólatra desde mocinha. Aí ela ficou noiva, a família conseguiu segurar as pontas, no primeiro ano de casada ela morava com a sogra, ela meio que se segurou. Aí ela ficou grávida. Quando nasceu a primeira filha - os sogros tinham armazém, atacado de secos e molhados - a sogra começou a perceber uma coisa estranha, aquelas bebidas estavam criando asas [...]. Começou a cuidar e descobriu. Aí o senhor foi lá, botou na prensa a família, a família confessou, mas que achavam que com o casamento podia [...]. Aí nesse meio tempo ela fica grávida pela segunda vez, então tiveram que abrir prá vizinhança toda, né, porque ela começou a ir na casa 
21 VALE DE ALMEIDA, 1995.

\footnotetext{
22 Aqueles homens que não são casados nem solteiros são os "deixados", pois, segundo meu interlocutor na ocasião, um estagiário de veterinária, "ninguém aguenta esses brutos [...]."
}

das pessoas roubar bebida. E aí, no fim, ela morreu quando esse segundo filho tinha uns sete, oito meses. Ela morreu porque ela passou a ingerir álcool puro.

Na tradição épica das narrativas gaúchas, os temas abordados por Dona Iracema e Simone raramente têm vez. O herói gaúcho, tanto da historiografia quando da literatura, além de ser masculino, deve ser exaltado por suas façanhas (novamente a ideia de prazer do desafio), e não por seus vícios e fraquezas. Estes, no entanto, acabarão tendo lugar nas narrativas orais, sobretudo naquelas contadas por mulheres.

Dando continuidade a essa reflexão, encontrei a sugestiva questão proposta por Vale de Almeida, ${ }^{21}$ em sua pesquisa sobre a masculinidade em Portugal, de que "o tempo também tem gênero". Dei-me conta de que, na fronteira, não só o tempo histórico pertence, de certa forma, aos homens, e o tempo cotidiano às mulheres, aparecendo em domínios narrativos diferenciados (narrativas épicas x segredos, fofocas), mas também a hora do dia em que se contam histórias difere, interferindo diretamente nas performances. Assim, enquanto os homens criavam certa solenidade sobre seus "eventos narrativos", ocorridos no final da manhã ou no cair da tarde, nas horas de folga, nos galpões, as mulheres me contavam histórias enquanto cozinhavam, lavavam louça, limpavam a casa, ou seja, suas narrativas vêm emolduradas por essas atividades, logo não caracterizam eventos autônomos para os quais deve ser destinada uma hora específica do dia.

As performances de uns e outros, dessa maneira, associam-se diretamente ao contexto desses eventos: os homens em geral permanecem sentados e gesticulam muito, fazendo largas pausas e silêncios; as mulheres movimentamse o tempo todo, utilizando os instrumentos referentes ao trabalho dentro da própria performance, e a narrativa de segredos ou intimidades aguça a percepção para ouvidos indesejados, o que por vezes cria um clima de mistério pelo uso de vozes sussurradas e olhares desconfiados.

\section{Organização social e relações de gênero na "Campanha"}

Nas estâncias da fronteira, sobretudo naquelas com maior número de empregados, cada família tem a sua casa ou os cômodos correspondentes a esta, e os peões solteiros, os que têm as mulheres na cidade, e os "deixados"22 dormem em quartos individuais ou coletivos, normalmente contíguos ao galpão. Como habitam em casas separadas, as mulheres em geral não participam dos momentos de reunião com os homens, como no caso das refeições ou das rodas de 
${ }^{23}$ Luciana HARTMANN, 2004b.

chimarrão no galpão. Embora não haja nenhum interdito explícito, a presença de mulheres no galpão é rara. Como eu tinha um interesse particular pelas narrativas que eram contadas no galpão, acabei enfrentando algumas dificuldades nesse sentido - e creio que só obtive sucesso porque possuía um status diferente das outras, as "suas" mulheres. A seguir, retomo a narrativa, já abordada em outro momento, ${ }^{23}$ de um episódio que representou o marco de minha verdadeira entrada em campo: ao iniciar minha pesquisa, numa das maiores fazendas do lado brasileiro da fronteira, minha primeira tentativa de entrar no galpão foi rapidamente frustrada por dois peões, que, parados em frente à porta, me deram solenemente o seu "Boa nôte", mas não se moveram do lugar. Sem precisar de grandes esforços para interpretar sua performance, compreendi que eu não só não tinha licença como não tinha espaço físico para passar. Resolvi não insistir. Depois de vários dias assistindo à telenovela com a cozinheira, acabei encontrando uma possibilidade inusitada de acesso ao galpão: o truco. Como eu fazia as refeições com os peões, numa noite comentei que gostava de jogar. Logo depois da janta, para minha surpresa, um dos peões bateu à porta da cozinha, onde eu já me preparava para assistir a mais um capítulo da novela, e me fez o convite enviesado: "Dona [...], nós tamo esperando a senhora lá no galpão". Dessa forma obtive a desejada permissão para entrar no galpão. Lá dentro o local já estava preparado para o jogo, com três cadeiras baixinhas dispostas de cada lado de uma pequena mesa de madeira. Divididas as parcerias, foi justamente a minha que ganhou o jogo. Nas noites seguintes voltei sistematicamente a ser convidada pois, segundo eles, "não há nada pior do que perder para uma mulher". Tudo isso acabou resultando numa relação bem mais próxima com os homens e me colocou em contato com seu palavreado menos formal e expressões, verbais e corporais mais espontâneas.

O truco, portanto, não apenas representou a real possibilidade de minha inserção nesse universo como me colocou em contato com os famosos "causos" contados nos galpões. E a partir desses "causos" masculinos, públicos, "de galpão", pude compreender melhor aquelas histórias contadas pelas mulheres em espaços mais privados, como cozinhas, salas ou quartos.

Voltando às mulheres, muitas delas, fossem patroas ou empregadas, acabavam assumindo uma postura maternal em relação a mim. Dessa maneira, tratada muitas vezes como filha, em pouco tempo eu me inseria no universo íntimo das famílias e, entre constrangida e feliz pela confiança que me era concedida, ficava sabendo de segredos, de desavenças familiares, de problemas nos negócios, de 
24 Janet Alison HOSKINS (1985), ao considerar a questão do "encontro etnográfico", salienta a importância de trazer para o texto não apenas o contexto dos informantes, mas as impressões desses sobre a pesquisadora (e vice-versa) e o impacto da pesquisa sobre eles. No meu caso, creio que a rápida inserção na intimidade das famílias que me hospedavam se deveu, em grande parte, a minha idade (pois muitos tinham filhos na mesma faixa etária) e, por outro lado, pela relação de "troca" que se estabelecia em nossas conversas, nas quais eu frequentemente expunha episódios de minha história de vida, ou seja, eu me contextualizava não apenas como pesquisadora mas como filha, irmã, amiga. Além desses aspectos, creio que outro fator foi fundamental: a vontade, a necessidade e o prazer que todos tinham de ser ouvidos, o que fez, ao longo da pesquisa de campo, com que eu me tornasse também uma grande "ouvidora".

25 Para um olhar sobre a constituição da masculinidade em bares, ver artigo de Denise Fagundes JARDIM, 1995. traições, de filhos ilegítimos, y otras cositas más. ${ }^{24}$ Então as mulheres também contam histórias? Sim, mas suas histórias referem-se a fatos da vida privada das famílias e, em geral, não podem ser divulgadas, logo não participam do repertório daquelas histórias contadas nos espaços públicos, mais especificamente, nas rodas de "causos" dos galpões.

Em outro sentido, e repensando a já clássica relação entre feminino/casa $x$ masculino/rua, percebo, surpresa com o potencial que meus dados etnográficos continuam oferecendo, que, se nas estâncias e nas cidades essa relação se confirma, ela se inverte no bolicho (bar, armazém, muitas vezes localizados às margens das estradas vicinais). De que maneira? Bem, lembro-me de mais de uma ocasião em que, nos finais de semana, os peões e suas famílias iam ao bolicho e que os homens permaneciam dentro do estabelecimento, enquanto as mulheres permaneciam fora, ao lado da casa, tomando mate e conversando. ${ }^{25}$ De certa forma, o interdito, o poluído, o impuro ali para elas era justamente o espaço interno e a rua representava uma garantia de integridade e "não contaminação". A contaminação, no caso, talvez fosse representada não pelo que elas eventualmente veriam, mas pelo que correriam o risco de ouvir nesse espaço segregado, onde se contam além dos "causos de salão", aquelas "anedotas picantes" (obscenas), proibidas para as mulheres.

As anedotas "picantes" ou "impróprias", como são chamadas, contêm obscenidades que os homens não costumam contar na presença de mulheres. Também são muito referidas pelo seu oposto "essas não são de salão". Bastante insinuadas durante toda a minha pesquisa de campo, só tive oportunidade de realmente ouvi-las quando estive numa roda de "borrachos" (bêbados), exclusivamente masculina, que se formou, à noite, num galpão de estância onde pernoitavam tradicionalistas gaúchos e alguns peões. Quando começaram a "soltar o verbo", alertaram-me: "a senhora não vai levar a mal as expressão, tá? A senhora sabe que [...] nós tamo aqui só a bombachada [...]", e no final me pediram muitas desculpas. A iniciativa de alguns gerou, inclusive, controvérsias e críticas por parte daqueles mais sóbrios:

Gaúcho 2: Se a senhora não levar a mal eu conto outra.

Eu: Claro que não.

Gaúcho 4: Não, peraí! [há discussões se ele deve continuar me contando ou não] Deixa a moça, senão ela vai correr daqui [...].

Gaúcho 1: É que ela vai levar uma imagem de que o gaúcho tem que ser grosseiro [...].

Gaúcho 2: Mas não é, rapaz, não é bagaceirada, é coisa típica [...] campeira. 
Ainda que seja "coisa típica", creio que dificilmente eu teria essa mesma oportunidade se aqueles homens estivessem sóbrios, pois a ética estabelecida para sua relação com as mulheres (e ao que lhes cabe ouvir ou fazer) não permitiria esse comportamento. De qualquer forma, graças a essa conjunção de fatores, pude ter acesso, no contexto de uma performance masculina, às famosas, mas frequentemente ocultas, narrativas "impróprias" às mulheres (o que não significa que elas as desconheçam). Essa ética gaúcha/masculina, embora mascarada durante as performances que presenciei das anedotas "impróprias", ficou evidente nos comentários que as sucederam, abordando o inusitado da situação:

Seu Solon: Por isso existe a tradição que mulher não entra no galpão, agora tu viu, é por causa disso aí.

Eu: Mas é por isso é que eu gosto de entrar no galpão, porque eu quero ouvir.

Gaúcho 1: Não, eu acho assim, né, uma mulher que se dispõe a enfrentar essas coisas, tudo bem. Mas na nossa cozinha ali [...] se ouve barbaridade! $A$ senhora desculpe [...] mas isso não se faz por maldade.

\section{O gênero e a divisão de papéis}

Assim como para Dona Rosa, às mulheres que moram nas estâncias (já que as proprietárias, atualmente em grande número, dificilmente vivem na Campanha, mas nas cidades próximas) são reservados serviços de cozinheira, lavadeira, faxineira etc. Elas em geral vêm acompanhando seus maridos e, em alguns casos, apesar de eventualmente trabalharem para os patrões, não recebem salário (ouvi, inclusive, diversas reclamações a esse respeito, pois elas têm ampla consciência da exploração de seu trabalho, não remunerado).

Nessa zona de fronteira, a sociedade se organiza, especialmente no âmbito rural, numa hierarquia que pode ser verificada mais claramente na divisão do trabalho das estâncias, mas que se reflete (e é refletida) também na organização do espaço físico, como foi visto acima, nas relações sociais, de amizade e parentesco. A noção de hierarquia, na região, construiu-se paradoxalmente ao ideal de "demo-

${ }^{26}$ FLORES, 1996; e Ruben George OLIVEN, 1992. cracia rural", ${ }^{26}$ que pressupunha uma relação igualitária entre patrões e empregados - incluindo também os negros escravos - e que durante muito tempo foi propagado por um setor da elite intelectual e política do estado. Essa hierarquia parece ter surgido, portanto, concomitantemente ao processo de organização das estâncias, que sedentarizou os tropeiros e que abrigou os homens que vagavam por aquelas terras até então sem fronteiras nem cercas (num certo sentido cercando- 
27 OLIVEN, 1992, p. 50. os também). Muitos deles vagabundos, coureadores, contrabandistas e ladrões de gado eram chamados até aquele período - meados do século XIX -, pejorativamente, de gaúchos. Acostumados à errância, esses homens tiveram de se adaptar à nova identidade que lhes era imputada, nas figuras de peões ou de soldados, agora subordinados aos grandes proprietários rurais ou aos militares e notabilizados através da mesma palavra "gaúcho", porém já "ressemantizada"27 e utilizada com sentido positivo.

Contemplando uma série de funções bastante específicas, as relações hierárquicas muitas vezes são permeadas não apenas pela divisão de trabalho, mas por outros aspectos da organização social. Os homens executam trabalhos com o gado (peões campeiros) e de manutenção (os chamados ajudantes "a pé", denotando o fato de não utilizarem cavalos em seu serviço), e as mulheres realizam os trabalhos de casa. Os que executam serviços para toda estância estão subordinados ao capataz (em $99 \%$ dos casos um homem) e os que executam serviços para a "casa-grande" - casa dos patrões - estão subordinados diretamente a estes. A única função feminina que permite ascendência sobre outro empregado homem é a de cozinheira. Na Estância São Paulo, por exemplo, Dona Rosa pode determinar tarefas para o ordenhador ou para o hortaleiro (que são "a pé" e por isso permanecem mais próximos da casa), mas as ordens finais sempre dependem do capataz.

No entanto, também aqui, a despeito da hierarquia formal entre as categorias de trabalho, as relações de parentesco, como já foi dito acima, também vão ajudar a conformar (e a transformar) as relações de poder e subordinação. Dessa forma, como esposa do capataz, a doceira da "casagrande" (tarefa que por si só não tem ascendência sobre as outras) detém, pela conjugalidade, maior "capital simbólico", possui maior poder que as outras mulheres, esposas de peões, e isso acaba determinando uma rearticulação na ordem hierárquica do serviço doméstico. Refletindo sobre essa questão, pergunto-me se em relação aos contadores de "causos" poder-se-ia pensar numa crença no poder e na legitimidade da palavra e/ou da performance. O poder simbólico representado pela performance narrativa seria, assim, capaz de "exercer efeitos reais sem dispêndio aparente de energia". ${ }^{28}$

Ainda assim, é importante perceber que no topo da hierarquia estão prioritariamente os homens. As únicas muIheres com autoridade para ultrapassar a "dominação masculina", ${ }^{29}$ e não apenas contrapô-la com "poderes secundários ou intersticiais", ${ }^{30}$ são as proprietárias de estâncias, 0 que confirma uma questão já percebida por Julian PittRivers $^{31}$ de que a autoridade de mulheres aristocratas vem relacionada à classe à qual pertencem, e não ao sexo. 
${ }^{32}$ Margareth MEAD, 1988.

${ }^{33}$ Sônia MALUF, 1993.

\footnotetext{
${ }^{34}$ Diane Louise WOLF, 1996, ao falar dos "dilemas femininos na pesquisa de campo", aborda a problemática da definição do papel ocupado pela antropóloga (andrógina, criança, homem honorário). A autora, no entanto, pontua a questão de gênero com outras possíveis identificações, como classe ou raça, e salienta que o acesso aos espaços restritos aos homens muitas vezes se dá através de conexões por laços de parentesco (com pai, marido, irmão). No meu caso, em geral um homem assumia um "cuidado" sobre mim e no caso do truco, citado acima, creio que meu saber só teve legitimidade porque contei que fui ensinada "por meu irmão".
}

E voltando à questão da legitimidade para contar histórias, ainda que tenham sido poucas, algumas mulheres também foram indicadas como contadoras. No entanto, essas mulheres em geral eram referidas devido à sua idade avançada e longo conhecimento da história da região (o que as igualava a alguns homens) e muito pouco em relação à sua performance, como se pode perceber na fala de Seu Wilmar: "Lá na Dona Eva era bom de levar ela. E lá é bem fácil de vim, dá prá vim até a cavalo! [...] Ela conta muita coisa, porque é gente muito antiga, e gente que tinha muito ouro ali né". Essa forma de caracterização das mulheres contadoras permite uma aproximação àquela teoria desenvolvida por Margareth Mead $^{32}$ (e desenvolvida em etnografias brasileiras como a de Sônia Maluf) ${ }^{33}$ de que mulheres que já ultrapassaram a fase fértil seriam, em muitos sentidos, igualadas aos homens, podendo passar a ocupar papéis ou funções tradicionalmente masculinas.

Meu papel como pesquisadora também identificavase de forma ambígua em relação aos gêneros pois, apesar de ser mulher, eu executava tarefas de e com homens, fazia as refeições com eles, acompanhando-os para todos os lados e, especialmente, compartilhava das narrações de suas histórias. Devido a essa proximidade, durante todo o período da pesquisa tive o cuidado de usar roupas discretas $e$, de certa maneira, tentei construir (ingenuamente) certa neutralização de meu papel. ${ }^{34}$ Apesar de meus esforços, no entanto, não pude evitar algumas situações constrangedoras.

Se por um lado o fato de ser mulher poderia trazer implicações indesejáveis para uma pesquisa que pressupunha inserção em espaços quase que exclusivamente masculinos, por outro lado tenho a plena consciência de que, em muitas ocasiões, somente por ser mulher é que tive acesso a locais e eventos privilegiados, pois para muitos homens/narradores, fossem peões ou proprietários de estâncias, era um orgulho contar seus "causos", mostrar o campo, o gado, os troféus, as fotos, para "essa moça da cidade", tão interessada em suas vidas e suas histórias.

\section{O que as narrativas contam sobre os papéis de gênero}

Como coloquei acima, há, na região pesquisada, uma nítida divisão entre os papéis de gênero que pode ser percebida na diferenciação do trabalho, do espaço e do tempo ocupados por homens e mulheres. Toda essa diferenciação é reproduzida (mas também produzida) nas performances de contadoras e contadores de "causos", em seu gestual, sua voz, sua postura. E o conteúdo de suas narrativas, o que diz a esse respeito? 
35 Geneviève CALAME-GRIOULE, 1987.

${ }^{36}$ CALAME-GRIOULE, 1987, p. 26.

${ }^{37}$ HARTMANN, 2004a.

${ }^{38}$ Estes conceitos têm origem na obra de Roman JAKOBSON (citado por Charles BRIGGS, 1996), que atenta para a importância de uma forma particular de dialogismo que emerge nas narrativas, fazendo com que elas simultaneamente representem "eventos narrativos" - a situação discursiva da sua narração - e "eventos narrados" - as palavras e as ações que eles relatam. Richard BAUMANN, 1986, tem enfatizado em seus trabalhos essa orientação dual das narrativas orais, que, segundo ele, fornece uma importante base para a realização do comentário social através da forma narrativa.
Impossível neste momento não referir o trabalho de Geneviève Calame-Grioule ${ }^{35}$ sobre os Dogon, em que a autora busca, nas relações entre a palavra, a língua e a sociedade, o que chama de "uma sociologia da linguagem". Segundo ela, "considerada sob o ângulo social, a palavra é também a expressão de regras que tornam possível a vida em sociedade, cujo conhecimento é transmitido por um ensinamento oral". ${ }^{36}$

Como abordo em minha tese de doutorado, ${ }^{37}$ a sociedade da fronteira caracteriza-se por uma oralidade fortemente desenvolvida e valorizada, daí o infindável repertório de narrativas orais e a existência da categoria "contador/ contadora de 'causos"' como responsável pela transmissão desse conhecimento, seja da história oficial, de anedotas ou de suas próprias histórias pessoais, todas elas formas narrativas que informam sobre uma forma de ser e de se relacionar em sociedade. É nessa perspectiva que procurarei desenvolver a seguir, ainda que sucintamente, algumas hipóteses acerca da configuração das narrativas masculinas e femininas na construção e na transmissão dos saberes desse grupo.

Olhemos inicialmente para as mulheres: nas histórias contadas por elas, é comum que as protagonistas também sejam mulheres, representadas pelas próprias contadoras, por pessoas da comunidade, por heroínas santas ou mesmo por bruxas, entre outras. A fim de explicitar o posicionamento das mulheres da fronteira tanto nos "eventos narrados" (o conteúdo, o que é contado) quanto nos "eventos narrativos" 38 (suas performances), trago a seguir três narrativas. Na primeira, ocorrida em Moirones, um pueblo uruguaio, as duas contadoras, uma parteira e a outra lavadeira, revezam-se no ofício de resgatar a memória de um fato ocorrido no local, mas oculto por seus protagonistas. Na segunda, Dona Eládia, de 56 anos, cozinheira de uma estância em Sant'Anna do Livramento, narra sua versão da história da Princesa Anastácia. Finalmente, a terceira narrativa, contada por Gringa, de 47 anos, empregada doméstica em Uruguaiana, relata um episódio de contato com uma bruxa.

Dona Araceli: De antes não é agora, que a gente se governa, pero de antes não [...]. A gente sofria muito [...]. [fala sussurrando - quase incompreensível] Tu te lembra aquela que se foi com o Bruno, do Pocho [...] e que os pais deram de penitência de encerrar ela não sei quantos anos, e que davam comida só com as rejas das cordas [...].

Dona Gegê: Essa que o [...]. Diz que ele sacou ela de casa e que ela se foi com ele [...].

Dona Araceli: Se serviu dela o [...] o do ônibus, muchacha! Ela se foi no ônibus, se enamorou do homem do ônibus, do ônibus que passava! Se foi 
[...]. E ele se serviu dela e foi-se embora, não é? Soltou ela e ela teve que se vir pra casa dos pais. $E$ a penitência [...] diz que os pais queriam matar ela. Diz que tinham ela encerrada numa peça só e davam a comida no meio [...] meio da reja [...] [as últimas frases são sussurradas]

Dona Gegê: $E$ só a mãe aparecia.

Dona Araceli: Só a mãe, o pai não queria ver ela nunca mais, eu acho que nunca mais viu, não é? Que sorte que não ficou embarazada, mas teve toda uma vida [...] nunca más casou nem nunca más [...].

Dona Gegê: Quando sacaram dessa peça que ela tava, diz que ela se foi de muda, não é?

Dona Araceli: [sussurando] Se foi [...]. Se foi pra outro país! Ela mora não sei aonde [...]. De antes, deus nos defenda! Tu fazia qualquer uma coisa mas sofria despôs, eu nem vou falar!

Dona Eládia: Tu vê, eu tenho a [...] tenho a Princesa Anastácia aí no meu quarto [refere-se a um quadro]. $A$ Princesa Anastácia foi uma negra escrava, mas como o patrão gostava muito dela [...] - o patrão era bom, a mulher era ruim. Como o patrão era boníssimo prá Anastácia, ela [...] não era escrava, era de dentro de casa. Com oito anos ela fazia curas, importante curas. Então o patrão tinha ela [...] como uma princesa, por isso ela é a Princesa Anastácia [...]. E a mulher dizia: "Por que é que tu quer tanto essa negra?" Claro, ela fazia cura, qualquer doença que tu tinha ela te curava. Pequenininha, menina assim. Aí a mãe da Anastácia quando teve a Anastácia teve nos currales, aqueles currales né, escondida dos patrão. Aí quando a mãe da Anastácia teve a Anastácia, morreu de tuberculose. E os patrão criaram a negrinha. O homem era bom. Tá. O Simão, que era o pai da Anastácia, de tanto porrete que davam nele, ele morreu, atado né, no tronco, sem comer, sem [...] não sei quantos dias sem comer, sem beber, sem nada. Aí a Anastácia já tinha quinze anos quando botaram o Simão, o pai dela, no tronco, sem comida, sem água, sem nada. Aí ela agarrou a roubar água dos patrão, da patrona. Rapadura [...] água [...] tudo prá levar prá ele. E um dia ela vai saindo da [...] não é dispensa, no tempo dos escravo era outra coisa que dizia. E aí a mulher perguntou: "Prá quem é que tu leva isso que tu tem na mão?" E o patrão não tava, tava viajando, o patrão. Quem cuidava da Anastácia era o patrão. Então, sabe - que é que a pobrezinha levava? Um pedacinho de rapadura na mão, água [...]. Pro Simão não morrer, prá dar na boca dele lá, prá botar na boca dele. Ai minina de Deus, tu sabe o que é que fizeram com a Anastácia enquanto o homem não tava? Porque eram a patrona e a ermã. Botaram a Anastácia no tronco. 
Com a boca amarrada, botaram uma coisa de ferro aqui [demonstra com gestos] e uma coisa de ferro no pescoço. E aqui ó [demonstra], botaram umas corrente de ferro. Quando o patrão veio e disse assim: "CadêIhe a Anastácia?", e a mulher disse: "A Anastácia eu botei no tronco, ela tinha pegado [...]." Então botaram as coisa assim nela, aquelas coisa de ferro [...] mas deu gangrena em tudo isso aqui ó [demonstra]. Aí, quando o patrão veio que levaram ela prá Rio de Janeiro e no Rio de Janeiro ela morreu. É milagrosa ela. É a santa milagrosa!

Gringa: Pois é, diz que [...] quando o primo do meu marido era pequeno, diz que [...]. Quando uma criança não é batizada, diz que a bruxa chupa pelo umbigo da criança, contavam, prá pegar a alma da criança. $E$ diz que uma entrou, quanto quanto que a [...] a tia do meu marido entrou no quarto [...]. Eram duas tias, uma que criou ele, a tia Lina e a tia Elisa. Entraram no quarto, diz que tinha um pato rosa em cima do berço assim [demonstra através de gestual]. Aí pegaram uma toalha assim [demonstra] e começaram a dar-Ihe pau nela. Diz que ela voava pelo quarto, bem louca! Diz que é um pato bem rosa. Depois que ela conseguiu sair pela janela diz que dava gargalhada! Diz que passou por cima da casa assim depois, voando, e dava gargalhada! E quando ele passa lá em casa, de noite, ele diz: "Olha a bruxa, Gringa!" - "Que bruxa?" - "Ó! Escuta a gargalhada.".

Percebe-se nas três narrativas que a relação entre vítima e algoz, que constitui o "drama" das histórias, não corresponde à dualidade feminino $x$ masculino. Enquanto na primeira narrativa os homens - motorista e pai da moça - são os principais antagonistas (embora não possamos subtrair a participação da mãe), na segunda e na terceira são também mulheres que ocupam o papel de "vilãs". Passemos a uma análise um pouco mais detalhada do conteúdo e da performance (o evento narrado e o evento narrativo) de cada uma dessas narrativas:

a) na primeira, a frase "De antes não é agora, que a gente se governa" revela um estado passado, imposto às mulheres, de subordinação aos homens, e a complementação: "[...] a gente sofria muito" demonstra uma identificação das contadoras com a mulher mencionada na história. Ao introduzir a narrativa situando esse contexto de subordinação das mulheres "de antes" em contraposição às do presente, Dona Araceli consegue, assim, explorar a ideia de punição, podemos pensar, para a mulher que quis "se governar". Em relação à performance, o diferencial reside no fato de a narração ser compartilhada pelas duas mulheres, que estabelecem uma espécie de parceria entre narrador 
${ }^{39}$ BAUMAN E BRIGGS, 1990.

principal (Dona Araceli) e narrador secundário (Dona Gegê). As duas desenvolvem atitudes semelhantes, com pouco uso de gestual e nenhuma movimentação no espaço (permanecem sentadas), enfatizando a performance vocal, como nos múltiplos sussurros que sugerem o tema interdito da narrativa;

b) na segunda, os personagens masculinos, patrão e pai, enfatiza a contadora, eram bons, e, embora a "patrona" fosse má, é outra mulher, Anastácia, que oferece o modelo de bondade, dedicação e heroísmo. Como explica Dona Eládia, apesar de ser princesa, de possuir o dom de curar, de ter cuidado do pai, Anastácia acabou morrendo em suplício, promovido pela esposa do patrão e por sua irmã. De certa forma, suas virtudes foram também sua desgraça. $E$ o cuidado que o patrão lhe devotava não apenas não fol suficiente para livrá-la da triste morte como também pode ter sido a causa desta. Em sua performance, Dona Eládia utiliza-se do recurso da reported speech, ou seja, da representação das falas das personagens em primeira pessoa. De acordo com Bauman e Briggs, ${ }^{39}$ esse é um dos principais dispositivos utilizados pelos contadores para conectarem os eventos narrados aos eventos narrativos. A contadora também busca interação com a audiência através do uso de perguntas como "fu sabe [...]?". Gesticulando bastante durante toda a narração, ela põe especial ênfase na demonstração dos instrumentos de tortura e do sofrimento de Anastácia, o que confere grande dramaticidade à história que está sendo narrada; e

c) na terceira, a bruxa aparece como personagem liminar, entre natural e sobrenatural, entre masculino e feminino. Uma das formas da bruxa, conta Gringa, é a de um "pato rosa". Nesta narrativa, o pato, embora seja um ser da natureza, é rosa e voa pelos ares, soltando gargalhadas, o que indica uma anormalidade "sobrenatural". O fato de se metamorfosear em um pato (e não em uma pata) alude, ainda que muito sutilmente, ao universo masculino. As tias, personagens femininos presentes na história, conseguem evitar que a bruxa, transgressora, "roube a alma" do menino, que ainda não foi batizado e por isso encontra-se desprotegido. Único personagem masculino da narrativa, o menino é a vítima, mas depois de adulto ironiza o episódio, procurando causar medo em uma mulher, a contadora. Sobre a performance de Gringa, essa é marcada, já de início, pela expressão "diz que". Ao usar esse recurso, estabelecendo-se como disclaimer da própria performance, a contadora minimiza sua responsabilidade pelo que está sendo contado. Em relação ao gestual, Gringa enfatiza a luta entre as mulheres e a bruxa, estabelecendo dessa forma, pela ação, o clímax da narrativa. Ela também recorre ao reported speech, representando diferentes personagens, caracterizados através de diferentes vozes. 
Longe de ser exaustiva, essa sucinta análise, restrita ao âmbito deste artigo, procura expor o potencial interpretativo que as narrativas contêm, sobretudo quando se colocam em relação aos eventos narrados e aos eventos narrativos, procurando, dessa forma, compreender o conteúdo narrado através do seu contexto de narração e das estratégias dos sujeitos que as contam.

Antes de finalizar, gostaria de retomar uma questão já colocada de que as mulheres contam preferencialmente para outras mulheres, em ambientes de intimidade, o que propiciou que ouvisse também muitos segredos. Nesses, o papel da mulher é sempre enfatizado, seja em relação ao assédio sexual sofrido por uma delas de um padre da região, seja nas aventuras extraconjugais do esposo, dono de estância, ou ainda na revelação da homossexualidade de um peão ou de um filho. Foram revelados, dessa maneira, fatos que me surpreenderam e por vezes me deixaram em uma posição delicada, pela confiança que me era dedicada. Fundamentalmente, foram essas pequenas histórias entrecortadas, nem sempre completas, fragmentos de discursos, que me possibilitaram uma visão mais completa e profunda das relações sociais na região. E embora nas narrativas contadas pelas mulheres os personagens femininos estejam em relevo, nelas verifica-se também a presença de personagens masculinos. Já nos "causos" narrados pelos homens, histórias mais "completas", públicas, com início, meio e fim, os personagens femininos, em muitos casos, simplesmente inexistem.

Apesar das limitações da análise aqui proposta, já explicitadas, creio que seja possível demonstrar que, entre as mulheres contadoras de causos, haja uma tendência em direção às temáticas relacionadas a segredos e histórias da intimidade, enquanto entre os homens, para as narrativas épicas, grandiosas. No entanto, a pesquisa de campo exibiu uma realidade tão multifacetada que por vezes fica difícil traçar generalizações, enquadrar seres de carne e osso, mulheres ou homens, em categorias analíticas. Embora insista na recorrência - temática e performática - de narrativas diferenciadas por gêneros, devo esclarecer que também presenciei mulheres contando "causos" em galpões ou em outros espaços públicos, assim como ouvi homens emocionados contando, em tom de confissão, episódios menos 'nobres' de suas histórias de vida.

De uma forma ou de outra, a constatação de que as mulheres representam uma parcela relevante dos contadores nessa região levou-me a salientar a participação delas

${ }^{40}$ Sobre a noção de "comunidade de narrativa da fronteira", ver HARTMANN, 2006. nesse quadro, conferindo a justa relevância às suas histórias, memórias e performances na composição da comunidade narrativa da fronteira. ${ }^{40}$ Assim, ainda que o objetivo deste 
${ }^{41}$ Ouvi uma vez de Dona Nilza, moradora de uma estância no lado brasileiro da fronteira, o seguinte comentário: "É lindo morar na campanha [...]". Fiquei pensando que talvez esse seja o campo das mulheres, a campanha, no feminino. trabalho tenha sido abordar o gênero numa perspectiva relacional, creio que tenha deixado pontos a desejar no tocante ao lado masculino da moeda, mas como este foi o lado normalmente priorizado no "cara e coroa" da história, talvez essa pequena tentativa de reequilíbrio seja justificada. Sem culpa. ${ }^{41}$

\section{Referências bibliográficas}

BAUMANN, Richard. Story, Performance and Event: Contextual Studies of Oral Narrative. Cambridge: Cambridge University Press, 1986.

BAUMAN, Richard; BRIGGS, Charles. "Poetics and Performance as Critical Perspectives on Language and Social Life." Annual Review of Anthropology, Palo Alto: Annual Reviews, v. 19, p. 59-88, 1990.

BOURDIEU, Pierre. O poder simbólico. Tradução de Fernando Tomaz. Rio de Janeiro: Difel, 1989.

BOURDIEU, Pierre. A dominação masculina. Rio de Janeiro: Bertrand, 1998.

BRIGGS, Charles. "Introduction." In: BRIGGS, Charles (Ed.). Disorderly Discourse: Narrative, Conflict and Inequality. New York/Oxford: Oxford University Press, 1996. p. 3-40.

CALAME-GRIOULE, Geneviève. Ethnologie et Langage. Paris: Institut d'Ethnologie, 1987.

CAGGIANI, Ivo. Sant'Ana do Livramento. 2. ed. Prefeitura Municipal de Sant'Ana do Livramento, 1990.

CONNELL, Robert William. Masculinities: Knowledge, Power and Social Change. Berkeley and Los Angeles, Califórnia: University of California Press, 1995.

FLORES, Élio Chaves. No tempo das degolas: prática $x$ discurso e revoluções imperfeitas. Porto Alegre: Martins Livreiro, 1996.

GROSSI, Miriam. "Identidade de gênero e sexualidade". Antropologia em Primeira Mão: PPGAS/UFSC, n. 24, p. 115, 1998.

HARTMANN, Luciana. "Aqui nessa fronteira onde tu vê beira de linha tu vai ver cuento": tradições orais na fronteira entre Argentina, Brasil e Uruguai. 2004a. Tese (Doutorado em Antropologia Social) - Universidade Federal de Santa Catarina, Florianópolis, 2004a.

HARTMANN, Luciana. "Histórias do tempo delas: performances de contadoras de causos da Campanha do Rio Grande do Sul". In: RIAL, Carmen Sílvia Moraes; TONELI, Maria Juracy (Orgs.). Genealogias do silêncio: feminismo e gênero. Florianópolis: Mulheres, 2004b. p. 95-103.

HARTMANN, Luciana. "Narrativas orais, uma porta de entrada para a 'cultura da fronteira' entre Argentina, Brasil e Uruguai”. In: CHIAPPINI, Lígia; MARTINS, Maria Helena 
(Orgs.). Cone Sul: fluxos, representações e percepções. São Paulo: Hucitec, 2006. p. 167-190.

HERZFELD, Michael. The Poetics of Manhood: Context and Identity in a Creatan Mountain Village. Princeton University Press, 1985.

HILL, Jane; IRVINE, Judith (Eds.). Responsability and Evidence in Oral Discourse. Cambridge: Cambridge University Press, 1993.

HOSKINS, Janet Alison. "A Life History Both Sides: The Changing Poetics of Personal Experiences." Journal of Anthropological Research, v. 41, n. 2, p. 147-169, 1985.

HOWELL, Signe; MELHUS, Marit. "The Study of Kinship; the Study of Person; a Study of Gender?" In: DEL VALLE, Teresa. Gendered Anthropology. London/New York: Routledge, 1993. p. 38-53.

JARDIM, Denise Fagundes. "Performances, reprodução e produção de corpos masculinos". In: LEAL, Ondina Fachel (Org.). Corpo e significado: ensaios de Antropologia Social. Porto Alegre: UFRGS, 1995. p. 193-205.

LANGDON, Esther Jean. "Performance e preocupações pósmodernas em Antropologia". In: TEIXEIRA, João Gabriel. Performáticos, performance e sociedade. Brasília: UnB, 1996. p. 23-28.

LANGDON, Esther Jean. "A fixação da narrativa: do mito para a poética da literatura oral". Horizontes Antropológicos, ano 5, n. 12, p. 13-36, 1999.

LANGDON, Esther Jean. "Performance e sua diversidade como paradigma analítico: a contribuição da abordagem de Bauman e Briggs". In: $31^{\circ}$ ENCONTRO ANUAL ANPOCS, 2007, Caxambu/MG. Mesa-redonda: Performance, drama e ritual: a formação de um campo e a experiência contemporânea.

LEAL, Ondina Fachel. Gauchos: Male Culture and Identity in the Pampas. 1989. Tese (Doutorado em Antropologia) University of California at Berkeley, 1989.

LUTZ, Catherine. "The Gender of Theory." In: BEHAR, Ruth; GORDON, Deborah (Ed.). Women Writting Cultures. Berkeley/Los Angeles/London: University of California Press, 1995. p. 249-266.

LYOTARD, Jean-François. O pós-moderno. Tradução de Ricardo Corrêa Barbosa. 2. ed. Rio de Janeiro: José Olympio, 1986.

MALUF, Sônia. Encontros noturnos: bruxas e bruxarias na Lagoa da Conceição. Rio de Janeiro: Rosa dos Tempos, 1993.

MEAD, Margaret. Sexo e temperamento. São Paulo: Perspectiva, 1988.

MOTA, Clarice. "Por uma antropologia da mulher". Encontros com a Civilização Brasileira, Rio de Janeiro: Civilização Brasileira, n. especial, p. 31-48, 1980. 
MOUFFE, Chantal. "Por uma política da identidade nômade". Debate Feminista (Cidadania \& Feminismo), n. especial, p. 266-278, 2000.

OLIVEN, Ruben George. A parte e o todo: a diversidade cultural no Brasil-nação. Petrópolis: Vozes, 1992.

PESAVENTO, Sandra. História do Rio Grande do Sul. 7. ed. Porto Alegre: Mercado Aberto, 1994.

PISCITELLI, Adriana. "Tradição oral, memória e gênero: um comentário metodológico". Cadernos Pagu, IFCH/ UNICAMP, n. 1, p. 149-171, 1993.

PITT-RIVERS, Julian. "Honra e posição social". In: Honra e vergonha (valores das sociedades mediterrânicas). 2. ed. Lisboa: Fundação Calouste Gulbenkian, 1988. p. 11-60.

SANT'ANNA, Elma. O folclore da mulher gaúcha. Porto Alegre: Tchê, 1984.

SCOTT, Joan. "Gênero: uma categoria útil de análise histórica". Educação e Realidade, Porto Alegre, v. 16, n. 2, p. 522, jul./dez. 1990.

TONKIN, Elizabeth. Narrating our Pasts: The Social Construction of Oral History. Cambridge: Cambridge University Press, 1992.

VALE DE ALMEIDA, Miguel. Senhores de si: uma interpretação antropológica da masculinidade. Lisboa: Fim de Século, 1995.

WOLF, Diane Louise. "Situating Feminist Dilemmas in Fieldwork." In: . Feminist Dilemmas in Fieldwork. Oxford: Westview Press, 1996. p. 1-55.

[Recebido em maio de 2008 e aceito para publicação em junho de 2009]

\begin{abstract}
From Countryside to "Campaign": Gender, Performance and Oral Narratives in Brazil and Uruguay Border's

Abstract: This article focuses on questions concerning the configurations of the gender roles among the female and male storytellers at Brazil/Uruguay border, taking into consideration the role of the researcher in this context. The differences of gender were gradually revealing its importance in the study of the oral narratives and, consequently, in understanding the frontier society, in the context of the present ethnography. The sexual division of work, time and space present in the local social organization is expanded to the oral narratives as well as to their performances. I intend to explore how these aspects, on narrative contents and/or on the way they are told, are being constructed while these differences are being delimitated.
\end{abstract}

Key Words: Orality; Narrative Performances; Frontier; Gender Roles. 